\title{
An Investigation into Food Balance and Its Relationship to the Physical Activity Practised within the School Context for Both Males and Females Aged 10-13 Years
}

\author{
Louh Hichem $^{1}$, Asli Houcine ${ }^{2}$ and Zerguine Saddek $^{2}$ \\ Institute of Physical Education and Sports, University of Mohamed boudiaf, Oran 31000, Algeria \\ Institute of Physical Education and Sports, University of Abdelhamid Ibn Badis, Mostaghanem 27000, Algeria
}

\begin{abstract}
The preliminary aim of this study was to reach food balance (quantitative and qualitative) of the meals provided by the school canteen at the Wilaya of Tieret, and its relationship to the physical activity practised, adequately through using a definite method to weight the amounts of food distributed for the meals, and to calculate the energetic expenditure of the physical activity, with an informative exploration of data and the value standards of the dispensed energy that is highly recommended by the (CNRS/CNERA 1992) center. The results of the main findings revealed that the value of macronutrients was smaller than the approved standards. Additionally, the value of the total protein weight per a day was $49.23 \mathrm{~g}$, the fat value as $24.11 \mathrm{~g}$ and carbohydrate value as $190.87 \mathrm{~g}$. The results showed also that protein diversity, animal and vegetal fats did not match the standards since the animal protein ratio was $27.76 \%$ and the vegetal as $72.24 \%$ from the whole total of protein. The percentage of the vegetal fat was $43.49 \%$ and the animal $56.31 \%$. Moreover, there is a weak correlation between the value of the expended and consumed energy. The Pearson's coefficient of males reached 0.09- and 0.39- for females. Furthermore, the value of the consumed energy did not fit the standards recommended for both males and females ages between 10/13 years old. On the basis of the previous pieces of information, we majorly recommend the achievement of a similar investigation for the rest parts of the country in order to reach a balanced nutrition for our children on internal schools.
\end{abstract}

Key words: Food balance, macronutrients, school canteens, physical activity.

\section{Introduction}

The healthy nutrition symbolizes an important element for the human's growth and the continuation of his life, and basically for the preservation of his health since food is considered as the "fuel" that provides us with energy and activity. The nature of diet needed varies by the child, the athlete and the adult or the pregnant woman, the elderly person or the patient. Each one of them has his own private needs of food.

In this current study, we will shed light on the nature of diet in internal schools for children aged between 10-13 years old. Reasonably, this period of life is characterized by huge changes in growth, and the

Corresponding author: Louh Hichem, Ph.D., professor, research field: sports physiology. E-mail: louh_hicham@yahoo.fr balanced diet plays a pivotal role in that process from the physiological, mental and kinetic manners [1]. Hence, the imbalance of diet (quantitative, qualitative) leads directly to malnutrition whether by its increase or decrease. Moreover, César et al [2] confirms that malnutrition is the lack of balance between the diet and the recommended standards whether being macro or micro nutrients. Additionally, considerable pieces of research have proved that short stature is highly associated with malnutrition [3]. Thus, we have done an analytic study about food balance at schools for both males and females aged between 10-13 years old, and starting from this research we have suggested the following aims: (1) To assess the nutritional balance (qualitative and quantitative) of the dietary meals distributed; (2) To assess the energetic consume of food for the pre-mentioned research sample in 
harmony with the Standard World Center for Research;

(3) To compare the expenditure energy -through the physical activity- with the intake energy of the dietary meals per a day.

\section{Research Terms}

\subsection{Macronutrients}

Macronutrients highlight the basic elements that are highly consumed by human beings. They gather a category of the chemical proportions that are needed greatly. These macro nutrients could be: protein, fats and carbohydrates $[4,5]$.

\subsection{Balanced Diet}

The balanced diet reflects in its essence the notion of equality in terms of proportions, merely by having a balanced consume of protein, carbohydrates, fats, minerals and water [6].

\subsection{School Canteens}

The school canteens are majorly the responsible upon the production and the distribution of meals. This indicates food quality and effective management for the deliverance of good food service [7].

\subsection{Physical Activity}

Physical activity embodies any type of movement through which the energy can be utilized such as: walking, gardening, briskly pushing a baby stroller, climbing the stairs, playing soccer, or dancing. For health benefits, physical activity needs to be equilibrated [8].

\section{Basic Study}

\subsection{Research Methodology}

With the aim of reaching valuable data and concrete information, the researcher has precisely followed a descriptive study in this research.

\subsection{Research Population and Sample}

The research was conducted about an internal school whose total population is 600 pupils (males and females). It consists of 90 males and 110 females.

\subsection{Time Scope}

This investigation was undertaken in the Tiaret Internal School of "Tiaret" province from April to June in 2014 (Algeria).

\subsection{Research Instrument and Data Procedure}

The researcher has made an analysis on the selected food menu (breakfast, lunch, dinner) during a week, through using a definite way that denotes weighting the amounts of food elements for each meal. In order to realize that, we opted for a balance whose value is between $5 \mathrm{~g}-30 \mathrm{~kg}$, so that we can exploit the information and calculate the energetic value of the macro-nutrients.

$1 \mathrm{~g}$ protein $=4 \mathrm{kcal}$

$1 \mathrm{~g}$ gluside $=4 \mathrm{kcal}$

$1 \mathrm{~g}$ lipid $=9 \mathrm{kcal}$

The researcher has analyzed and calculated the weight of the macro nutrients of the animal and vegetal elements and calculated their ratio in comparison to their total weight, by using the Table of Food Composition (100 g) [9] and the recommended Nutritional Value Table (cnrs/cnerna 1992). Majorly, he has also calculated the energetic value of the physical activity practised, solely by measuring the stature using the "Istudio Meters" as an aid, and measuring the weight as well by a medical balance.

In a part, the investigator has calculated the basal expenditure energy per a day through utilizing this equation (Mifflin-St. Jeor):

- For men: $\mathrm{MB}=(10 \times$ weight in $\mathrm{kg})+(6.25 \times$ height in $\mathrm{cm})-(5 \times$ age in years $)+5$.

- For women: $\mathrm{MB}=(10 \times$ weight in $\mathrm{kg})+(6.25 \times$ height in $\mathrm{cm})-(5 \times$ age in years $)-161$.

And he also tended to calculate the expenditure energy depending on the physical activity:

- If you do not practise sport: $1.2 \times \mathrm{mb}$ 
- If you practise a mild activity (3 mild sessions) : $1.375 \times \mathrm{mb}$

- If you practise an average activity( 3 to 5 sessions in a week): $1.55 \times \mathrm{mb}$

- If you are very active (high intensity 6 to 7 sessions): $1.725 \times \mathrm{mb}$

- If you are very active (high intensity or an athlete): $1.9 \times \mathrm{mb}[10]$.

\subsection{Statistical Methods}

We opted for SPSS program to calculate: The arithmetic average, standard deviation, the maximum and the minimum value, Pearson correlation coefficient and Excel program as well to determine the percentage ratios of food that are distributed into the meal.

\section{Data Analysis and Discussion}

\subsection{The Discussion of the Meal Content}

We observed through the food menu given during the three meals (breakfast, lunch, dinner) per a week in the school canteen which follows:

(1) There is an elevation of the vegetal nutritional sources more than animal ones;

(2) There is no variety of the animal sources and a total absence of red meat;

(3) There is a total absence of the sea nutritional sources during the week;

(4) There is a limited variation in terms of fruits (apple, orange).
On the basis of these provided data, we could say that the distributed meals in the school canteen per a week do not fulfill the needs of this age period that is between 10-13 years old, from the menu and micro nutritional of protein and carbohydrate, fat and the mineral elements. So they affect the nature of growth of this specific age. This fact is shown through a total absence of the sea nutritional sources that contain phosphorus and calcium which are very important for growth.

\subsection{Discussion and Interpretation of the Main Findings}

\subsubsection{The Protein Value in the Three Meals}

The main findings revealed that the weight value of the total protein of the three meals (breakfast, lunch, dinner) that highlights 49-25 $\mathrm{g}$ (Tables 1, 2 and 3) is far from the recommended value of this age period (10-13) years old (males and females), according to (cnrs/cnerna 1992) center which indicates $66 \mathrm{~g}$ for males and $58 \mathrm{~g}$ for females.

We also noted that both animal and vegetal protein rations do not fit the recommended standards merely because the vegetal protein ratio was $72.24 \%$ and the animal protein was $27.75 \%$ (Table 4), while the recommended value is $50 \%$ for the animal protein and $50 \%$ for the vegetal protein. Additionally, the reason per a day in the school with the recommended standards is the lack of specialists who hold the needed competence to plan constructively for the values of the

Table 1 Evaluation of energy intake from breakfast and the contribution of calories in carbohydrate, lipid, protein in the meal.

\begin{tabular}{cccccccc}
\hline \multirow{2}{*}{ Days } & Calorie intake per child & \multicolumn{2}{c}{ Protein } & \multicolumn{3}{c}{ Fats } & \multicolumn{2}{c}{ Carbohydrate } \\
\cline { 2 - 8 } & cal & $\%$ & G & $\%$ & G & $\%$ & G \\
\hline Sunday & 61.03 & 14.65 & 2.23 & 33.99 & 2.30 & 51.34 & 7.83 \\
Monday & 237.79 & 14.53 & 8.64 & 12.78 & 3.37 & 72.68 & 43.20 \\
Tuesday & 61.03 & 14.65 & 2.23 & 33.99 & 2.30 & 51.34 & 7.83 \\
Wednesday & 237.79 & 14.53 & 8.64 & 12.78 & 3.37 & 72.68 & 43.20 \\
Thursday & 237.79 & 14.53 & 8.64 & 12.78 & 3.37 & 72.68 & 43.20 \\
Average & 167.09 & 14.58 & 6.07 & 21.26 & 2.94 & 64.14 & 29.05 \\
STDEV & 96.81 & 0.06 & 3.50 & 11.62 & 0.58 & 11.68 & 3.50 \\
max & 237.79 & 14.65 & 8.64 & 33.99 & 3.37 & 72.68 & 43.20 \\
min & 61.03 & 14.53 & 2.23 & 12.78 & 2.30 & 51.34 & 7.83 \\
\hline
\end{tabular}


Table 2 Evaluation of energy intake from lunch and the contribution of calories in carbohydrate, lipid, protein in the meal.

\begin{tabular}{cccccccc}
\hline \multirow{2}{*}{ Days } & Calorie intake per child & \multicolumn{2}{c}{ Protein } & \multicolumn{3}{c}{ Fats } & \multicolumn{3}{c}{ Carbohydrate } \\
\cline { 2 - 7 } & cal & $\%$ & G & $\%$ & G & $\%$ & G \\
\hline Sunday & 548.67 & 15.48 & 12.23 & 17.91 & 10.92 & 66.61 & 91.35 \\
Monday & 632.40 & 14.50 & 22.92 & 17.40 & 12.22 & 68.09 & 107.66 \\
Tuesday & 610.73 & 20.76 & 32.28 & 19.11 & 12.97 & 59.91 & 91.48 \\
Wednesday & 667.65 & 16.94 & 21.28 & 16.27 & 12.07 & 66.77 & 111.45 \\
Thursday & 624.39 & 13.93 & 21.75 & 16.25 & 11.28 & 69.80 & 108.95 \\
Average & 616.77 & 16.32 & 25.24 & 17.39 & 11.89 & 66.24 & 102.18 \\
STDEV & 43.48 & 2.73 & 4.20 & 1.20 & 0.81 & 3.75 & 9.91 \\
max & 667.65 & 20.76 & 32.28 & 17.91 & 12.97 & 69.80 & 111.45 \\
min & 548.67 & 13.93 & 12.23 & 16.25 & 10.92 & 59.91 & 9135 \\
\hline
\end{tabular}

Table 3 Animal protein and vegetable ratio existing in college protein value of the three meals.

\begin{tabular}{ccccccccc}
\hline \multirow{2}{*}{ Days } & Calorie intake per child & \multicolumn{2}{c}{ Protein } & \multicolumn{3}{c}{ Fats } & \multicolumn{2}{c}{ Carbohydrate } \\
\cline { 2 - 8 } & cal & $\%$ & $\mathrm{G}$ & $\%$ & $\mathrm{G}$ & $\%$ & $\mathrm{G}$ \\
\hline Sunday & 307.03 & 20.26 & 15.55 & 25.66 & 8.75 & 54.06 & 41.5 \\
Monday & 374.58 & 21.01 & 19.68 & 25.30 & 10.53 & 53.67 & 50.26 \\
Tuesday & 363.22 & 12.78 & 11.60 & 21.84 & 8.81 & 65.36 & 59.36 \\
Wednesday & 400.53 & 23.16 & 23.22 & 19.28 & 8.59 & 57.54 & 57.68 \\
Thursday & 404.53 & 19.32 & 19.45 & 21.67 & 9.74 & 59.00 & 59.67 \\
Average & 370.07 & 19.31 & 17.92 & 22.75 & 9.28 & 57.93 & 53.69 \\
STDEV & 39.32 & 4.73 & 4.45 & 2.69 & 0.82 & 4.73 & 7.81 \\
max & 404.53 & 23.22 & 23.22 & 25.66 & 10.53 & 65.36 & 59.67 \\
min & 307.03 & 12.78 & 11.60 & 19.28 & 8.59 & 54.06 & 41.5 \\
\hline
\end{tabular}

Table 4 Animal protein and vegetable ratio of total lipids found in the value of the three meals.

\begin{tabular}{ccc}
\hline Days & Protein (animal) & Protein \\
\hline Sunday & 40.92 & 59.07 \\
Monday & 24.62 & 75.37 \\
Tuesday & 21.94 & 78.05 \\
Wednesday & 12.88 & 78.11 \\
Thursday & 29.38 & 70.60 \\
Average & 27.76 & 72.24 \\
STDEV & 7.97 & 7.97 \\
max & 40.92 & 78.11 \\
$\min$ & 12.88 & 59.07 \\
\hline
\end{tabular}

nutritional meals distributed and their basic contribution for this age period (10-13 years). In correspondence to what have been discussed, Algeria is not classified among the countries that are suffering from malnutrition, according to the Organization of Food and Agriculture (UN Institute) "FAO" [11]. From the centrality of this issue, the main reason behind the rise of vegetal protein ratio in comparison to the animal one is due to the lack of animal nutritional sources such as red meat and fish. So the absence of these elements is the core problem since they do not fit the recommended standards, bearing in mind that the animal sources contain more protein than the vegetal ones [12]. Then, the lack of protein value may hold back the process of growth in this age period. Generally speaking, research has proved that the protein plays an essential role in growth and for the formation of hormones and enzymes [13]. Moreover, the protein provides our body with the needed energy for both the athlete and non athlete, merely for their basal 
expenditure energy [14].

\subsubsection{Fats Value in the Three Meals}

The data obtained from the tables clarified that the total fats value of the three meals (breakfast, lunch, dinner) was $24.11 \mathrm{~g}$ (Tables 1, 2 and 3), which does not fit the recommended standards by (cnrs/cnerna 1992) center that highlights $73 \mathrm{~g}$ for males and $65 \mathrm{~g}$ for females. Vegetable fats ratio was estimated as $43.51 \%$ and animal fats as $56.31 \%$ (Table 5). Although, it does not fit the recommended standards by (cnrs/cnerna 1992) center that highlights $40 \%$ for animal fats and $60 \%$ for vegetable fats. Several pieces of research have emphasized that the fat ratio in the animal sources is higher than the vegetal ones $[15,16]$. In other words, studies show that the greasy acids (Omiga-3) are very low in the vegetal nutritional sources [17]. So far, the animal nutritional sources such as fish that contains greasy acids (Omiga-3) have a pivotal role in curing depression, obsessive compulsive disorder and for the psychological stability as well [18]. In addition, the fat is an important source of energy for the athletes since: $1 \mathrm{~g}=9 \mathrm{kcal}$ [19].

\subsubsection{Carbohydrate Value of the Three Meals:}

The results obtained showed that the carbohydrate value of the three meals was $190.87 \mathrm{~g}$ (Tables 1, 2 and 3 ) and this value is far from the recommended one that is $273.75 \mathrm{~g}$ for males and $243 \mathrm{~g}$ for females (10-13) years old. We have observed that the carbohydrate ratio recommended for each meal is around 50-55 while it was about 60-65 in each meal.

The reason of these results is merely the inappropriate planning of the meals in the school canteen. Hence, this age is mirrored to be the most active of any other age period adequately through the notion of "playing". Pupils tend to consume more energy whether they are athletes or not. So the best and rapid source of energy is the "carbohydrate" and this was confirmed by researchers, adding that this element is the most consumed and widely used in the muscle. They also acknowledge that the carbohydrate can delay the athlete's fatigue, for this reason, it is wiser to increase its consume [20].

4.2.4 The Value of the Intake Energy and Its Relation to the Expenditure and the Recommended One

The results indicated that the value of the intake energy per a day was $1153.93 \mathrm{kcal}$ of both males and females. Furthermore, the expenditure energy of the physical activity was $1437.75 \mathrm{kcal}$ (males) and 1177 kcal (females) (Table 6). In dealing with that, the results of Pearson correlation coefficient was 0.09 (males) and 0.39 (females). Particularly See in Table 6,

Table 5 Animal fat and vegetable ratio of total lipids found in the value of the three meals.

\begin{tabular}{ccc}
\hline Days & Fats (animal) & Fats \\
\hline Sunday & 67.76 & 32.23 \\
Monday & 51.66 & 48.33 \\
Tuesday & 37.44 & 61.81 \\
Wednesday & 60.03 & 39.96 \\
Thursday & 64.66 & 35.23 \\
Average & 56.31 & 43.51 \\
STDEV & 12.16 & 11.90 \\
max & 67.76 & 61.81 \\
$\min$ & 37.44 & 32.23 \\
\hline
\end{tabular}

Table 6 The value of the intake energy and its relation to the expenditure and the recommended One according to (cns/cnerna1992) center.

\begin{tabular}{ccccccc}
\hline Age & Stature & Weight & Intake Energy & Expenditure Energy & $\begin{array}{c}\text { Pearson Correlation } \\
\text { Coefficient }\end{array}$ & $\begin{array}{c}\text { The recommended Intake } \\
\text { Energy CNS(1992) }\end{array}$ \\
\hline Male (Age 10-13) & 140.02 & 38.3 & 1153.93 & 1437.75 & -0.09 & 2190 \\
Female (Age 10-13) & 141.28 & 32.4 & 1153.93 & 1177.2 & 0.39 & 1950 \\
\hline
\end{tabular}


the value of the intake energy and the expenditure one-through the mild physical activity practised at school-was a weak correlation for both genders. Then, the value of the intake energy is totally far from the recommended one, especially in this age period.

To sum up, we can notify that there is malnutrition among the pupils aged between 10-13 years old. It has been emphasized that malnutrition is a term that reflects in its insights, an inadequate planning in the preparation of the meals, adding that its occurrence is not due to economic issues. Thus, there is no correspondence between the meals distributed and the recommended ones. On the other hand, we should also be aware of the negative sides of malnutrition such as: (1) It affects the kinetic learning process in specific and learning the basal school subjects in general; (2) Multiple studies show that effective learning is highly associated with the balanced nutritional meals, not least, the effect upon learning capacities and memorization [21].

\section{Results}

There is no adequacy of the quantity and variety of the protein (animal, vegetal) distributed in the school canteen, with the recommended standards of the (cnrs/cnerna 1992) center.

There is no adequacy of quantity and quality of the animal and vegetal fat distributed in the school canteen, with the recommended standards of the (cnrs/cnerna 1992) center.

There is no adequate quantity of carbohydrate, compared to the recommended standards of the (cnrs/ cnerna 1992) center.

There is no balance between the expenditure and intake energy among pupils (males and females).

There is no convenience of the intake energy with the recommended standards of the (cnrs/cnerna 1992) center for both (males and females).

\section{References}

[1] Avigon, A., Barlie, P., Basdevant, A., Bressou, J. L.,
Colette, C., Constans, T., and Cosmes, J. 2001. Cahiers of Nutrition and Dietetics. Paris France: ed Elsevier Masson, 1st edition, 21-9.

[2] Cesar, C., Larguèze, B., and Gaubert, C. 2000. Distance to the School World, "the Child's Autonomy" and Attendance of Half Board: The Disaffection of School Canteens in SeineSaint Denis Colleges. Accessed November 28, 2007. http://www.invs.sante.fr/publications/2007/abena2_2007/ abena_2.pdf (in French)

[3] David, F., Lori, R., and Charlene, C. 2005. "Comparison of Predictive Equations for Resting Metabolic Rate in Healthy Nonobese and Obese Adults: A Systematic Review." American Journal of Clinical Nutrition 105 (5): 775-89.

[4] Groot, D., Lindgren, G. C., and Lisbeth, F. 2010. "Older Adults' Motivating Factors and Barriers to Exercise to Prevent Falls." Scandinavian Journal of Occupational Therapy 18 (2): 153-60.

[5] Fotso, J. and Barthelemy, K. 2005. "Measuring Socio-economic Status in Health Research in Developing Countries: Should We Be Focusing on Households, Communities, or Both?" Social Indicators Research 72: 189-237.

[6] Fances, C. and Ellie, W. 2007. Nutrition: Concepts and Controversies. New York City: Cengage Learning, 26.

[7] Jacotot, B., and Capillo, B. 2003. Human Nutrition. Paris, France: Ed Elsevier MASSON, 311. (in French)

[8] Kessos, C. 2002. Structural Biochemistry. Paris, France: MASSON, 193. (in French)

[9] Labarthe, M. C. 1999. Practical Nutrition. France: Ed LAMMARRE, 117.

[10] Lairon, D. 2001. Dietary Lipids and Sterols in Clinical Nutrition Treaty Adults. France: Ed Flammarion Medicine Science, 153-64.

[11] Lakhan, S. E, and Vieira, K. F. 2008. "Nutritional Therapies for Mental Disorders." Nutrition Journal 7: 2.

[12] Kern, M. 2005. CRC Desk Reference on Sports Nutrition. London: Taylor \& Francis CRC Press, 117.

[13] Melchior, J. C. 2001. Undernutrition and Malnutrition in Clinical Nutrition treaty Ladulte, Paris: Flammarion Médecine-Sciences, 381-91..

[14] Schaible, U. E., and Kaufmann, S. H. 2007. "Malnutrition and Infection: Complex Mechanisms and Global Impacts." PLoS Med. 4 (5): e115.

[15] Steven, M. S. 2003. Economics: Principles in Action. Upper Saddle River, New Jersey: Pearson Prentice Hall, 481.

[16] Mifflin Company. 2005. New Dictionary of Cultural Literacy. The American Heritage, Third Edition, 672.

[17] Tremolliers, J., Serville, Y., and Jacquotr, M. 1984. "Manual Food of Human Food." Tome 2: Journal of 

School Context for Both Males and Females Aged 10-13 Years

Persee 2: 262.

[18] Umezawa, M., Kogishi, K., and Tojo, H. 1999. "High-linoleate and High-alpha-linolenate Diets Affect Learning Ability and Natural Behavior in SAMR1 Mice." J. Nutr. 129 (2): 431-7.
[19] Whitney, E. and Sharon, R. 2005. Understanding Nutrition, 10th edition. New York: Thomson-Wadsworth, 6.

[20] Xavier, B., and Charles, Y. 2007. Sports Nutrition. Paris, France: Elsevier Masson. 